\title{
Research on the Attribution of Investigative Power of Duty Crimes Against the Background of Supervision System Reform*
}

\author{
Gang Luo \\ Law School \\ Xinjiang University \\ Urumqi, China 830047
}

\begin{abstract}
The reform of the national supervision system is a major measure to promote the anti-corruption governance system and the modernization of governance capabilities. It is conducive to integrating anti-corruption capabilities, achieving full coverage of the scope of supervision, and ultimately improving the degree of anti-corruption rule of law. It is of great significance and far-reaching impact. The reform of national supervision system poses a challenge to the existing legal system of duty crimes. In the field of criminal litigation, the attribution of investigative power has become an important issue. The right to investigate duty crime has both administrative power and judicial power. This cognition eliminates the theoretical obstacles of the supervisory authority. Only by assigning the right to investigate duty crimes to the supervisory organs can the goal of the supervision system reform be achieved, and the heterogeneous supervision system for the separation of investigation and prosecution can be improved, and entity fairness and procedural justice can be realized.
\end{abstract}

Keywords-supervision system reform; duty crime; investigative power; new era; controversy on draft of supervision law

\section{INTRODUCTION}

State supervision system reform is the important issues of the system level in our country, its great significance, in this context has triggered a series of duty crime prosecution authority, fully realize the significance of rule of law, reform and as well as the rational adjustment of duty crime prosecution power, to make the system maximum effect in the future.

*Project: This article is the phased research results of Xinjiang University PhD initial funding "Research on Foreign Anti-terrorism Governance" presided over by the author (No. BS160107), the phased research results of key project of the liberal arts research base of General colleges and Universities of Xinjiang Uygur Autonomous Region, "Study on the anti-terrorism mechanism of urban public transport in Xinjiang province (No.: XJEDU010915A01)

\section{THE REALISTIC FOUNDATION OF THE REFORM OF NATIONAL SUPERVISION SYSTEM AND THE SIGNIFICANCE OF THE RULE OF LAW}

First, it is conducive to achieving full coverage of the scope of monitoring. In the object of supervision, the current administrative supervision law mainly targets the civil servants of the state administrative organs and other personnel appointed by the state administrative organs, resulting in a narrow scope of supervision. For the legislature, the judiciary, and state-owned enterprises and institutions, public officials in social organizations are not involved. There is a blind spot for monitoring. Therefore, reforming the national supervisory system and implementing a toplevel design on the constitution can solve such a dilemma in anti-corruption

Second, it is conducive to the integration of anticorruption capabilities. At present, there are many anticorruption agencies in China, including disciplinary inspection department, anti-corruption bureaus, and procuratorial organs. It is difficult to form synergies in practice. The functions of various anti-corruption agencies are overlapping, the boundaries are unclear, and the normative basis is different. It is different to form stable, standardized and efficient coordination and engagement mechanism. Taking the discipline inspection and supervision department and the procuratorial organ as an example, the former is an internal supervision system for ensuring that the staff of party and government organs obey the law and discipline, are clean and honest. The latter procuratorial organ is the national legal supervision organ confirmed by the Chinese Constitution, exercising the functions of investigation, prosecution, anti-corruption and rumors. These two organs have their own powers and are not affiliated with each other. Their functions are overlapping. The policies and regulations that lead to anti-corruption are not the same, which makes it difficult to achieve the seamless connection between party discipline, administrative punishment and criminal justice, and directly affects the punishment of corruption.

Third, it is conducive to enhancing the degree of anticorruption rule of law. On the one hand, according to the 
principle of the rule of law in which powers are mutually restricted, the right to investigate and the right to examine and prosecute should be exercised by different subjects. Then, it would achieve procedural justice. However, in the criminal justice of corruption crimes, the investigative power and the right to examine and prosecute of duty crimes belong to different departments. It is difficult for the procuratorial organs to avoid the investigation and prosecution of the same pattern. And the effect of the investigation and prosecution on the restriction of investigation power is worrying. The supervision also erodes judicial credibility. On the other hand, the procuratorate has the power to investigate the duty crime in accordance with the provisions of the Criminal Procedure Law. In fact, the "two regulations" measures of the Commission for Discipline Inspection and the "twofingered" measures of the current administrative supervision department are powerful means of anti-corruption. The substantive "detainment" to personal liberty for such a long time is suspected of violating the basic principles of the rule of law. At the same time, the discipline inspection department conducts preliminary investigations, fixes the evidence, and the procuratorial organs conducts the examination. In essence, the investigative power on duty crimes of the procuratorial organs is falsified, and the boundaries between discipline and law, discipline and law enforcement will be confused to some extent. It uses the discipline to replace the law. In other words, the investigation authority of the discipline inspection department for anti-corruption still lacks the clear authorization of the law, and the investigation power of the procuratorate is difficult to achieve practical results in the investigation of actual cases. Therefore, the goal of the reform of the national supervision system is to enrich the means of supervision through legal authorization, to establish a centralized, unified, authoritative and efficient anticorruption mechanism, and to promote anti-corruption work on the basis of the spirit of the rule of law.

\section{SUPERVISORY INSTITUTIONS HAVE THE RIGHT TO INVESTIGATE DUTY CRIMES UNDER THEORETICAL PREREQUISITES}

To solve the integration of the administrative supervision function and the duty crime investigation function under the background of departmental integration is essentially the connection between administrative law enforcement and criminal justice. During the monitoring and reform period, the old "Administrative Supervision Law" was still in force and the new "National Supervision Law" has not yet been introduced. A new-type and independent "national monitoring power" has not yet been shaped. It is a prominent problem to integrate the administrative supervision right as administrative enforcement right with the criminal enforcement right of public procuratorial organs. One of the most notable issues in the reform of the national supervisory system is the attribution of investigative power. This not only relates to the richness and legitimacy of the investigative agencies, but also determines the specific positioning of the supervisory organs and the procedural model of anticorruption criminal justice. Whether or not to give the supervisory authority the right to investigate not only affects the top-level design at the constitutional level, but also is revolutionary amendment to the criminal procedure law.

There are different opinions in the academic world regarding the attribution of investigative power. According to the theory of limited expansion, the supervisory authority cannot certainly have the right to investigate. In order to carry out the anti-corruption practice, it can be given some of investigative power. For example, Professor Ma Huaide believes that the powers of the procuratorate for investigation, arrest, public prosecution, etc. cannot be enjoyed by the supervisory committee. The state inspection committee can only have the right to investigate, not the detection right. The two cannot be equal. Considering the need to effectively exercise the right to investigate, it may be given the power to retrieve information and even enter, detain, and seal the premises. The full expansion of powers holds that if the supervisory authority is defined as a state anti-corruption agency and the corresponding authority of the procuratorate to handle duty crimes is transferred to the supervisory authority, there will be no problem for the investigative power to belong to the supervisory authority. From the perspective of the nature, detection power is an inseparable and extremely important part of investigative power.

The author believes that from the factual level, the judicial attribute of the investigative power of duty crime is prominently reflected in the criminal procedure law as the legal basis. Finally, it enters the trial. It should naturally follow the principle of equity review and restriction. The administrative attributes intensively are reflected in the authority and discretion of the investigation process, and are subject to the functionality of the leadership relationship of the administrative system. Therefore, there is a factual basis for the dual attributes. From the normative point of view, the right to investigate the duty crimes cannot be based solely on facts. Law is a normative discipline, which contains value evaluation. Therefore, the qualification of investigative power of duty crime is also worthy of value. In fact, from the essence of qualitative arguments, whether administrative or judicial power, the essence of the differences lies in the different paths of supervision of investigative power. And this difference leads to the conflict between combating crime and safeguarding the balance of human rights. It should better consider the inherent requirements of the eternal theme of justice and efficiency. Therefore, it examines the attribution of the investigation power of duty crimes from the perspective of the criminal procedure law. The focus of the investigation is to ensure that the investigation work is carried out efficiently and smoothly. Thereby, it should combat crimes and protect legal interests, as well as procedural justice and human rights protection. In practice, the style and characteristics of administrative power are more biased, leading to the impulse to abuse power. It is necessary to impose certain restrictions on judicial concepts and procedures, and to protect the legal rights of criminal suspects on the basis of cracking down on crimes. All countries in the world classify investigative procedures as criminal litigation activities, which is of great significance for limiting investigative power based on the criminal procedure. [1] Therefore, it gives the duality of 
administrative power and judicial power to investigative power of duty crimes. And it can achieve a dynamic balance between justice and efficiency. It can be said that the dual attributes are appropriate to examine the nature of the investigation power of duty crimes from the facts and norms.

\section{THE SUPERVISORY ORGANS HAVE THE RIGHT TO INVESTIGATE DUTY CRIMES}

It is theoretically feasible for the supervisory authority to enjoy the right to investigate duty crimes. It is also quite necessary in the practice of anti-corruption.

First, the right to investigate duty crimes is in the scope of investigation and supervision. The right to investigate duty crimes is an important part of the supervision power, and it is the legal means and measures to supervise the diligent and honest administration of state organs and their staff. In nature, it is the law enforcement investigation power in anti-corruption, which can be derived from the logical and normative supervision power. The Constitution of the People's Republic of China stipulates that the People's Procuratorate is the state's legal supervisory authority. It exercises the procuratorial power independently according to law. And it is not subject to interference by administrative organs, social groups and individuals. Based on this, the investigative power of duty crimes is given to the prosecution. Nowadays, the supervision system reform is implemented. The supervisory committee is the supervisory law enforcement agency, which is responsible for investigating and handling duty crimes. Its supervision and enforcement powers should investigate the illegal and noncriminal punishment rights and investigate the criminal investigation power of corruption crimes. To supervise the relationship between the law enforcement rights and the investigation power is a problem that should be solved by the top-level design of the Constitution. It cannot be ignored that if the anti-corruption-related functions are transferred from the procuratorate to the supervisory committee, and it doesn't give the investigation right. And it is unbelievable.

Second, there are precedents for the transfer of such investigative powers. In the historical evolution of the allocation of investigative power in China, the subject change of the investigative power and the boundary of authority are inevitable requirements that constantly adapt to the trend of social development. At first, the public security organs and the procuratorate have the right to investigate. However, the specific division of investigative power is not clear. With the promulgation of laws and regulations such as the Criminal Procedure Law and the Organic Law of the People's Procuratorate in 1979, the investigative authority has been improved day by day. At the same time, the subject of investigative power has also changed in response to the needs of the times. After the establishment of the state security organ in 1983, the investigative power of the national security is transferred from the public security organ to the security organ. The investigation of the corresponding cases originally undertaken by the public security organs is also logically placed under the jurisdiction of the state security organs. Therefore, the transfer of investigative power with the establishment of a new institution is in line with the actual needs.

Moreover, in a strict sense, this is not related to the new legal issue of the investigative power of duty crimes. In the context of the reform of the supervision system, it is related to the distribution of the investigative power among the subjects, the definition of the specific content of the investigative power, the question of coordinating the relationship, and the allocation of investigative power. In this way, on the transfer of the right to investigate duty crimes of duty, there is no need to worry too much about the improper expansion of the scope of investigation power. In the case of the incremental setting of investigative power, it is necessary to consider a series of deeper problems such as the necessity of authorizing legality.

Third, the empowerment of investigative power can achieve the goal of monitoring system reform. China has always attached importance to the rule of law on duty crimes and implemented zero tolerance for corruption. The administrative and judicial resources on the crackdown on duty crimes are not enough: administrative inspection agencies at all levels, audit departments, and anti-corruption agencies. Such a large number of institutions have the function of preventing and punishing corruption. In terms of form, it seems to form a strict legal network to combat corruption. In fact, due to the scattered conflicts of institutions and the inconsistency of functions, the standards are different. And it is difficult to connect, which greatly reduces the usage efficiency of anti-corruption resources. Correspondingly, the means of duty crime is constantly intelligent, concealed and diversified. The internal relationship of crime is complicated. The power and money transaction has a wide range of radiation and many links. It often crosses departments, industries and cross-disciplines, and the anti-detection capability is continuously enhanced. It is more difficult to investigate. [2] Therefore, the traditional duty crime investigation mode and institutional setup have been difficult to adapt to the new situation of duty crimes, and it is urgent to reform and effectively integrate. The goal of the supervision system reform is to address the new situation of anti-corruption, and to further improve and promote anti-corruption work by building an efficient and unified anti-corruption agency.

The most crucial thing to severely punish corruption is to further strengthen anti-corruption investigation capabilities. Judging from past practice, the supervisory authority has the right to investigate, which has more restrictions and limited effect. As a result, in actual work, it is often necessary to rely on a strong coordination mechanism to coordinate the public security organs, procuratorial organs and other institutions to successfully complete the investigation of duty crimes. With the transfer of the jurisdictional power of the procuratorial duty crimes, if the supervisory authority is not given the criminal investigation power in the future, it is difficult to cope with the increasingly complicated situation of duty crimes, and it is impossible to achieve the ultimate goal of the supervision system reform. 
Fourth, the right to investigate duty crimes can be given to the supervisory organs, and the system of supervision and investigation of prosecutions for crimes can be improved to achieve fairness and justice. The current law in China stipulates that the investigative powers of duty crimes and the power to examine and prosecute all belong to the procuratorate. They are carried out by different departments of different procuratorates. They are all affiliated to the procuratorate, and the supervision of investigative powers is inevitably disturbed. In the form, it is not conducive to the realization of procedural justice while combating duty crimes. If the right to investigate duty crimes is transferred to the supervisory institutions, the supervisory committee shall make the investigation and the procuratorial organ shall review and make a decision of prosecution. It will realize the transformation of the same-body supervision mechanism of the duty crime to the variant supervision mechanism, and increase the rigidity of the power restriction. At the same time, it has created conditions for the controversial "doubleregulation" measures, which fundamentally enhances the credibility of anti-corruption.

\section{CONCLUSION}

The nation should deepen the reform of national supervision system, establish a unified and efficient supervision system, implement organizational and institutional innovation, integrate anti-corruption resources, expand the scope of supervision, enrich the means of supervision, severely punish corruption acts, and build an effective mechanism that the staff don't dare to rot or perish. It is the fundamental purpose of the reform of the national supervisory system. Under this premise, giving the investigative power to the supervisory authority is an inevitable requirement for establishing an authoritative and efficient supervision system. It will not only trigger and lead to the collapse of justice, but also will further promote the procedure, legalization and standardization of investigating duty crimes.

\section{REFERENCES}

[1] Zhang Yuxiang. "Criminal Investigation", Peking University Press, 2014, p. 11.

[2] Ding Yinghua. "The nature of investigative power of duty crimes in China", China Prosecutor, No. 23, 2015.

[3] Qin Qianhong. " Research on reform of state supervisory system ", Law Press, 2018, p. 98.

[4] zhang Xinxiang. " Risk and prevention of duty crime", Law Press, 2017, p. 118. 